\title{
Power to Gas-Electrochemical industry hybrid systems: A case study
}

\author{
Manuel BAILERA $^{\mathrm{a}}$, Sergio ESPATOLERO ${ }^{\mathrm{b}}$, Pilar LISBONA ${ }^{\mathrm{c}}$, Luis M. ROMEO ${ }^{\mathrm{a}}$ \\ ${ }^{a}$ Escuela de Ingeniería y Arquitectura. Universidad de Zaragoza, \\ Campus Río Ebro, María de Luna 3, 50018, Zaragoza, Spain \\ ${ }^{\mathrm{b}}$ Research Centre for Energy Resources and Consumption (CIRCE), \\ CIRCE Building - Campus Río Ebro, Mariano Esquillor Gómez, 15, 50018, Zaragoza, Spain \\ ' Escuela Universitaria de Ingenierías Agrarias de Soria - Universidad de Valladolid, \\ Campus Universitario Duques de Soria, 42004, Soria, Spain
}

\begin{abstract}
Several researchers have proposed in literature different Power to Gas (PtG) hybridizations to improve the efficiency of this energy storage technology. Some of the synergies of this hybrid systems are already being tested under real conditions (e.g. PtG-Amine scrubbing, PtGwastewater treatment) while others have only been studied through numerical simulations (e.g., PtG-oxyfuel combustion). Here, a novel hybridization between Power to Gas and electrochemical industries is proposed for the first time. This PtG-Electrochemical hybridization avoids to implement the typical water electrolysis stage of PtG since hydrogen is already available in the plant. This study thoroughly analyzes the implementation of Power to Gas in a real electrochemical plant that sub-produces hydrogen from the lines of production of chlorate, chlorine, and potassium hydroxide. It is shown that the required carbon dioxide for methanation can be captured from the flue gas of the factory's boilers without additional energy penalty thanks to energy integration. The methanation plant has been designed according to the $\mathrm{H}_{2}$ and $\mathrm{CO}_{2}$ availability, taking into account the number of operating hours and the degree of usage of by-products. Results show that this PtG hybridization could operate more than 6000 hours per year at large scale concepts (nominal $\mathrm{H}_{2}$ inputs of 2000
\end{abstract}


$\left.\mathrm{m}^{3} / \mathrm{h}(\mathrm{NTP})\right)$, which represents $2000 \mathrm{~h}$ more than pilot/commercial demonstrations of classic PtG concepts. Besides, a detailed economic analysis demonstrates the economic feasibility of the system under current scenarios. It is shown that the capital investment would be recovered in 8 years, generating a $4.8 \mathrm{M} € \mathrm{NPV}$ at the end of the project lifetime. Thus, this work presents a suitable way to avoid the subsidy dependency that current PtG research projects have.

\section{Keywords}

Power-to-Gas, Methanation, Hybridization, Electrochemical industry

\section{Introduction}

In 2009, the European Renewable Energy Directive (2009/28/EC) established a global policy to achieve in 2020 a renewable share in the European final energy consumption for at least $20 \%$, together with a $10 \%$ share in the field of transport [1]. Beyond 2020, renewables will remain playing a key role since EU countries have already agreed on extending the target up to $27 \%$ by 2030 . According to the trends to 2050 from the "EU Reference Scenario 2016 ", the share of electricity produced from renewables is expected to grow up to $37.2 \%$ by $2020,43 \%$ by 2030 , and $53 \%$ by 2050 [2].

The intermittent nature of these renewable energy sources (RES) produces mismatches between supply and electrical demand that affect the security and stability of the grid. Typically, generators and system operators can only regulate the 5-10\% of the output coming from variable renewable sources (wind and solar). For instance, the degree of regulation in Spain is about 5\%, in Sweden 6\% and in Germany 7\% [3]. Hence, the increase of renewable share in the electricity production mix brings along with fluctuating power that limits the operational predictability and flexibility of the energy system, generating a serious challenge 
to electrical grid operators. To promote RES deployment, embedding energy storage techniques into conventional power stations and industries result essential to smartly manage renewable intermittent power.

In the last years, Power to Gas (PtG) has been proposed as a very promising and versatile technology to store renewable power surplus. PtG converts electricity into synthetic natural gas via the methanation of $\mathrm{CO}_{2}$ together with $\mathrm{H}_{2}$ from water electrolysis [4][5]. This technology widens the application of hydrogen as energy vector, and it makes possible to produce a $\mathrm{CO}_{2}$ neutral fuel by capturing the carbon emissions from an existing source [6][7]. In addition, it allows the connection between electric and gas network thus increasing the flexibility of the energy supply system. However, significant economic barriers slow down PtG development due to the current high cost of electricity, and the large required investments. These problems could be overcome through hybridizing systems whose synergies increase the global efficiency, improve the resource use, and reduce the investment on new equipment [8].

In 2009, Michael Sterner outlined several configurations that present some synergies depending on the $\mathrm{CO}_{2}$ source used for the methanation process (biogas, syngas or pure $\mathrm{CO}_{2}$ ) [9]. For instance, the use of biogas avoids the necessity of a carbon capture step since biogas is already a mixture of $\mathrm{CH}_{4}(50 \%-85 \%)$ and $\mathrm{CO}_{2}(50 \%-15 \%)$ [10]. Besides, it allows the integration of the methanation heat in the digestion processes. For those reasons, the most recently developed PtG pilot plants prefer biogas as source of $\mathrm{CO}_{2}$ [11]. In 2015, Electrochaea commissioned the largest plant worldwide integrating biogas as resource [12], in which a 1.0 MW alkaline water electrolyzer supplies the hydrogen [13]. They aim to integrate both the byproduct oxygen and the methanation heat in the wastewater treatment process that generates the biogas [14]. Technical data from this field experience have not been released yet, but 
previous projects showed that 3000 operating hours were achievable under realistic market conditions [15].

Likewise, syngas from gasification does not require a carbon capture process either, and permits the use of the by-produced oxygen during water electrolysis to carry out oxygen-blow gasification. This type of integration is still under development at lab/pilot scale [11], so there are no studies quantifying the benefits of the integration. The cutting-edge research in this topic is carried out by the Karlsruhe Institute of Technology, which has made some methanation tests with input flows of syngas of $14 \mathrm{~m}^{3} / \mathrm{h}$ (NTP) [16] in a biomass gasification plant belonging to Cortus, in Sweden [17].

Power to Gas plants that make use of pure $\mathrm{CO}_{2}$ admit different integration configurations. When amine capture technology is employed, methanation heat may be integrated and used for regenerating the solvent. If oxy-fuel combustion capture technique is used, mass flow integration is possible and the by-produced $\mathrm{O}_{2}$ is used as comburent.

The PtG-Amine integration case is the only one that has a commercial experience, the Audi egas plant [18]. It uses three alkaline water electrolyzers of 2.0 MW [19] and produces up to $325 \mathrm{~m}^{3} / \mathrm{h}$ (NTP) of synthetic natural gas [20]. Besides, the plant is qualified for participating in the electricity balancing market [21], and the availability of the renewable energy consumed gives about 4000 operating hours per year [20]. Specific software had to be developed to optimize the thermal management of the waste heat recovered from electrolysis and methanation, to be later supply in the $\mathrm{CO}_{2}$ removal plant [21][22]. The objective of the manufacturer, ETOGAS, is to reach PtG systems around $20 \mathrm{MW}$ with efficiencies above $80 \%$ thanks to the recovery of the methanation heat [23]. Regarding Power to Gas-oxyfuel combustion hybridization, some studies based on simulations can be found in literature. Bailera et al. characterized these kind of systems and proposed district heating and industries 
as preferred applications [24][8]. Besides, they studied the application of PtG-Oxy hybridization in a combined cycle power plant, and showed that the $88 \%$ of the methanation heat can be integrated increasing the global efficiency of the power plant from $56 \%$ to $68 \%$ $[25]$.

Another hybrid route to store fluctuating power from renewables is the Power to Chemicals concept. Those chemicals that require hydrogen and carbon dioxide for their production (e.g., methanol, ethylene, propylene, and formic acid) act as hybrid storage of energy and $\mathrm{CO}_{2}$ when $\mathrm{H}_{2}$ is renewably produced with electricity surplus. In these cases, there is no investment related to the methanation stage of the classic PtG concept, since this stage is substituted with an already existing line of production of chemical products [26]. This kind of hybridization puts together the water electrolysis stage of classic Power to Gas concept with an existing chemical line of production that substitutes methanation (Figure 1). For instance, the CO2RRECT project produced hydrogen with renewable energy to reduce $\mathrm{CO}_{2}$ and obtain carbon monoxide, which is later used as precursor of other chemical products [27].

In this paper, we propose for the first time the Power to Gas-Electrochemical industry hybridization, a new type of integration that implements methanation in chemical plants whose lines of production are based on chemical electrolysis. Whenever a chemical electrolytic process generates hydrogen as by-product, it can be integrated in a PtG process (Figure 1). Thus, the PtG-Electrochemical hybridization avoids implementing the classical water electrolysis stage of PtG since hydrogen is already available in the plant. At the same time, the $\mathrm{CO}_{2}$ emissions from the electrochemical plant can be used in the methanation process. 


\section{POWER-TO-CHEMICALS}

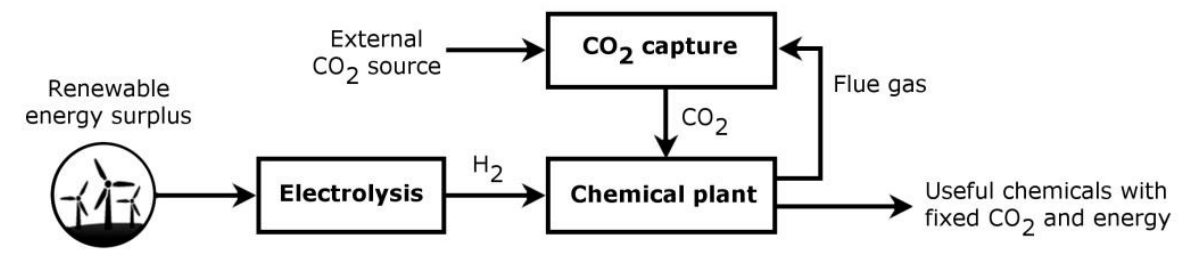

\section{PtG-ELECTROCHEMICAL HYBRIDIZATION}

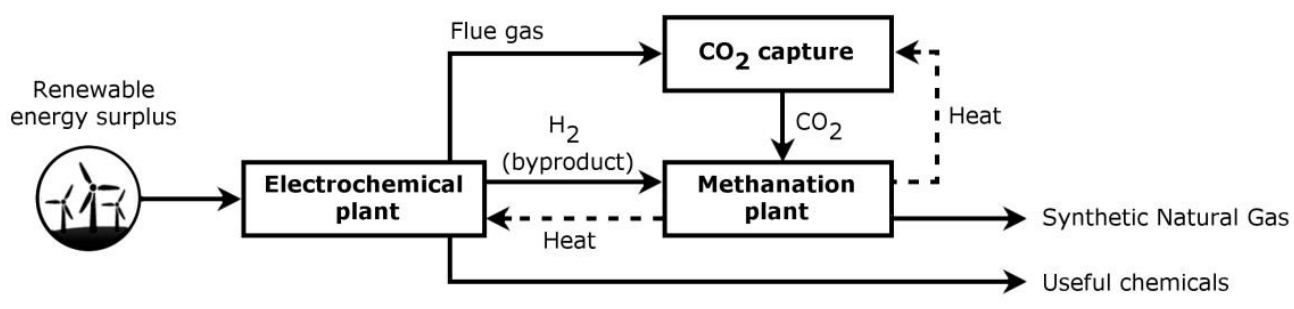

Figure 1. Comparison between the classical Power-to-Chemical route and the novel PtG-

Electrochemical hybridization.

The overall objective of the paper is to size a hybrid PtG-Electrochemical plant through its simulation under real operating data from a Spanish factory. The system includes an aminebased $\mathrm{CO}_{2}$ capture plant, a TREMP methanation plant, and an optimized heat exchanger network to energetically integrate both facilities. The relation between the operating hours of the different sub-systems is a key parameter when sizing the Power to Gas plant, and it determines the degree of $\mathrm{H}_{2}$ and $\mathrm{CO}_{2}$ utilization, as well as the size of the required buffer of $\mathrm{H}_{2}$ to manage the resource. The study concludes with an economic analysis of the proposed hybrid system.

\section{Case study: Power to Gas-Electrochemical hybridization}

In PtG-Electrochemical hybridizations, the electricity used is no longer considered as consumption in the factory but as stored energy (it should be noted that the conversion of electricity to hydrogen will have lower efficiency than conventional water electrolyser). This hybrid concept avoids most of the large investment costs (water electrolysers) and an important part of the operational costs (electricity) associated to classical Power to Gas plants. 
These costs are removed since hydrogen is directly provided -i.e., by-produced- through other already existing electrochemical processes in the plant. In addition, carbon dioxide could be supplied from the boilers present in the electrochemical plant with low energy penalties thanks to the integration of the heat released in the methanation reaction.

We present here a case study of an existing plant with a significant amount of byproduct hydrogen coming from two electrolytic production lines: sodium chlorate $\left(\mathrm{NaClO}_{3}\right)$, Eq. (1), and chlorine $\left(\mathrm{Cl}_{2}\right)$ and potassium hydroxide $(\mathrm{KOH})$, Eq. (2).

$$
\begin{gathered}
\mathrm{NaCl}+3 \mathrm{H}_{2} \mathrm{O} \leftrightarrow \mathrm{NaClO}_{3}+3 \mathrm{H}_{2} \\
2 \mathrm{KCl}+2 \mathrm{H}_{2} \mathrm{O} \leftrightarrow 2 \mathrm{KOH}+\mathrm{Cl}_{2}+\mathrm{H}_{2}
\end{gathered}
$$

Currently, both sources of by-produced hydrogen are purified and mixed for further use. The $50 \%$ of the produced hydrogen is destined to ammonia $\left(\mathrm{NH}_{3}\right)$, the $25 \%$ to hydrochloric acid $(\mathrm{HCl})$, and the $20 \%$ to hydrogen peroxide $\left(\mathrm{H}_{2} \mathrm{O}_{2}\right)$; the remaining $5 \%$ are losses (Figure 2).

The proposed hybridization consists of replacing ammonia production with synthetic natural gas production, since the latter is a more profitable product. In addition, the methanation process could consume $\mathrm{CO}_{2}$ emissions from a boiler installed in the plant.

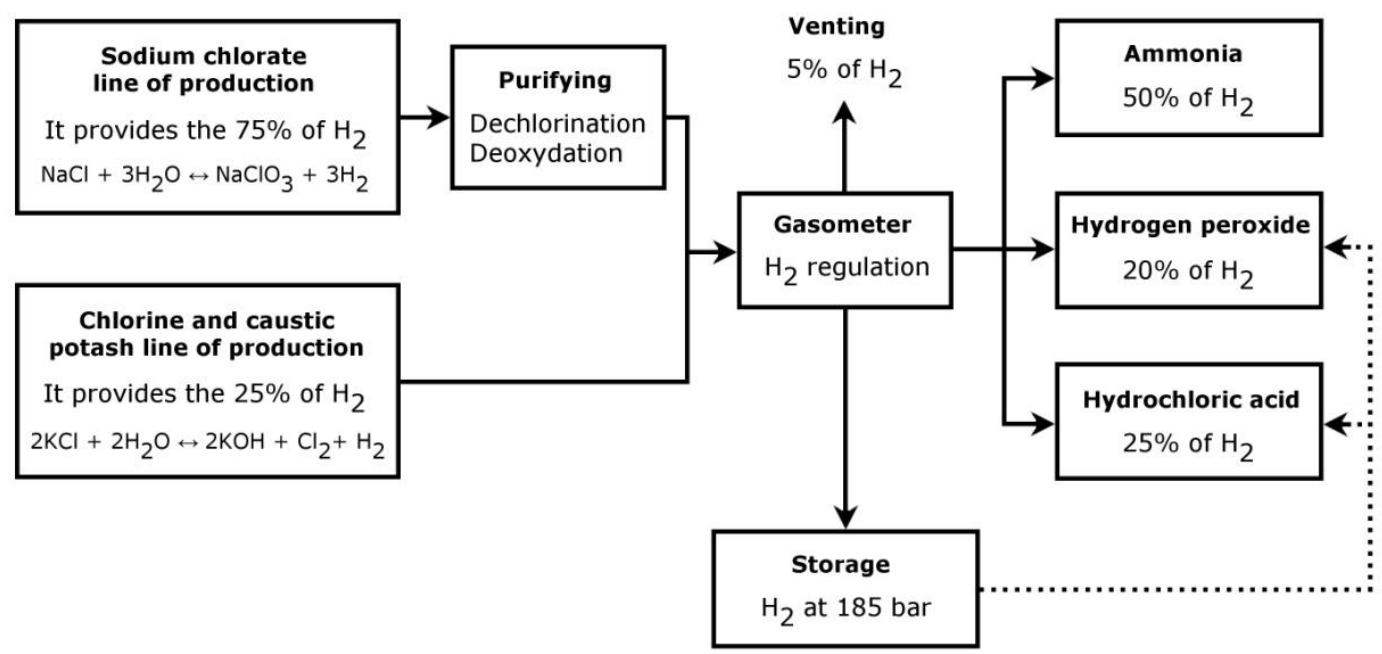

Figure 2. Scheme of the hydrogen routes in the electrochemical plant. 
The availability of hydrogen in the plant fluctuates following the electricity market in order to operate the chemical electrolysis during the periods of low electricity prices. This operating strategy limits the amount of $\mathrm{CO}_{2}$ that can be used in every period of time (Table 1). In this sense, January and February present potential $\mathrm{CO}_{2}$ utilizations below 60\%, whilst August usage capability is above $90 \%$. The maximum potential yearly consumption of $\mathrm{CO}_{2}$ reaches the $68 \%$ of total emissions, although this will be limited due to partial load operation restrictions in the methanation plant (periods of low $\mathrm{H}_{2}$ productions) and situations in which there is no enough $\mathrm{CO}_{2}$ to convert the temporarily available hydrogen.

In this work, we have analyzed the hourly production pattern of $\mathrm{H}_{2}$ to determine the actual potential of integrating Power to Gas in the selected electrochemical plant, with the aim of simulating the optimal-sized plant and performing a detailed economic assessment.

Table 1. Available $\mathrm{H}_{2}$, emitted $\mathrm{CO}_{2}$ and potential $\mathrm{CO}_{2}$ usable in PtG.

\begin{tabular}{|l|r|r|r|}
\hline Month & $\begin{array}{r}\mathbf{H}_{2} \text { available } \\
{\left[\mathbf{k m}^{\mathbf{3}} \mathbf{( \mathbf { N P } ) ]}\right.}\end{array}$ & $\begin{array}{r}\mathbf{C O}_{2} \text { emitted } \\
{\left[\mathbf{k m}^{\mathbf{3}} \mathbf{( \mathbf { N P } ) ]}\right.}\end{array}$ & $\begin{array}{r}\text { Max. CO2 usable } \\
{[\%]}\end{array}$ \\
\hline January & 1058 & 512 & 51 \\
\hline February & 1067 & 465 & 57 \\
\hline March & 1253 & 457 & 68 \\
\hline April & 1260 & 466 & 67 \\
\hline May & 1175 & 446 & 66 \\
\hline June & 1116 & 312 & 89 \\
\hline July & 949 & 387 & 61 \\
\hline August & 1670 & 452 & 92 \\
\hline September & 1179 & 483 & 61 \\
\hline October & 1303 & 367 & 89 \\
\hline November & 1078 & 353 & 76 \\
\hline December & 1007 & 471 & 53 \\
\hline Total & 14115 & 5171 & 68 \\
\hline
\end{tabular}

\section{Methodology}


The developed study comprises three main issues which have been sequentially approached: (i) the characterization of the hourly distribution of the $\mathrm{H}_{2}$ availability, (ii) the simulation of the hybrid plant, and (iii) the development of an economic evaluation.

\subsection{Evaluation of $\mathrm{H}_{2}$ availability, and plant sizing}

The chemical electrolysis lines of the plant present intensive energy consumptions, so their operations must follow the power market to reduce the operational costs. The electricity price varies among 6 time periods (P1 to P6) that are established by legislation [28][29]. It divides the year in 650 hours of P1, 3126 hours of P2-P5, and 4984 hours of P6 (Figure 3). Thus, the plant accordingly adapts the holidays and maintenances to mostly operate in Period 6 (the cheapest one), as well as diminishes the production load during periods P1 to P5. Finally, the hourly availability of $\mathrm{H}_{2}$ along the year is completely defined by also considering the unplanned shutdowns. The operating hours of the electrochemical plant throughout periods P1 to P6 are summarized in Table 2.

The largest by-production occurs when both chemical electrolysis lines simultaneously operate at Period 6 (the most economic period) thus giving a maximum of $4926.0 \mathrm{~m}^{3} / \mathrm{h}$ (NTP) (Table 2). However, only the amount that would be consumed in ammonia can be used in methanation, which is equal to the $50 \%$ of the by-produced $\mathrm{H}_{2}$. In addition, during Period 1 the by-produced hydrogen is very limited due to the high cost of electricity, and it is preferred to entirely dedicate it to the production of Hydrochloric acid and Hydrogen peroxide, instead of ammonia. Therefore, we also consider that during P1 there is no hydrogen available for methanation. 


\begin{tabular}{|c|c|c|c|c|c|c|}
\hline P6 & P2 & P1 & $\mathrm{P} 2$ & & $\mathrm{P} 1$ & $\mathrm{P} 2$ \\
\hline \multicolumn{7}{|c|}{ 16th-30th June, July (Working days) } \\
\hline P6 & $\mathrm{P} 2$ & IP & & & $P$ & \\
\hline \multicolumn{7}{|c|}{$1^{\text {st-15th June, September (Working days) }}$} \\
\hline P6 & \begin{tabular}{|l|l|l|l}
$P 4$ & $P 3$ \\
\end{tabular} & & & P4 & & \\
\hline \multicolumn{7}{|c|}{ March, November (Working days) } \\
\hline P6 & P4 & & & P3 & & P4 \\
\hline \multicolumn{7}{|c|}{ April, May, October (Working days) } \\
\hline $\mathrm{P} 6$ & P5 & & & & & \\
\hline
\end{tabular}

Figure 3. Hourly distribution of pricing period [28].

Table 2. Rates of by-production of $\mathrm{H}_{2}$, and chemical electrolysis parameters, for the six market periods.

\begin{tabular}{|l|r|r|r|r|r|r|}
\hline & \multicolumn{3}{|c|}{ NaCl electrolysis } & \multicolumn{3}{c|}{ KCl electrolysis } \\
\hline & P1 & P2-P5 & P6 & P1 & P2-P5 & P6 \\
\hline$\dot{\mathrm{V}}_{\mathrm{H} 2}\left[\mathrm{~m}^{3} / \mathrm{h}(\mathrm{NTP})\right]$ & 0.0 & 2333.0 & 3629.1 & 486.3 & 689.0 & 1296.9 \\
\hline$\dot{\mathrm{V}}_{\mathrm{H} 2 \text {,ammonia }}\left[\mathrm{m}^{3} / \mathrm{h}(\mathrm{NTP})\right]$ & 0.0 & 1166.5 & 1814.5 & 0.0 & 344.5 & 648.4 \\
\hline $\mathrm{h}[\mathrm{h} /$ year $]$ & 0 & 1581 & 4584 & 570 & 2846 & 4584 \\
\hline
\end{tabular}

The boiler of the electrochemical plant (the $\mathrm{CO}_{2}$ source) is operative $24 \mathrm{~h}$ per day, except those dates in which the facility is completely closed. Hence, the monthly emissions (Table 1) are equally divided between the operating days, what results in hourly emissions in the range $464-726 \mathrm{~m}^{3} / \mathrm{h}(\mathrm{NTP})$.

\subsection{PtG-Electrochemical hybrid plant model}

The proposed hybrid plant has been modelled and simulated in Aspen Plus ${ }^{\circledR}$, and then thermally integrated with Aspen Energy Analyzer through the Pinch analysis technique $[30][31]$.

\subsection{1 $\mathrm{CO}_{2}$ capture plant model}


Chemical absorption was considered the most suitable technology for $\mathrm{CO}_{2}$ capture to be integrated in the electrochemical plant. Thus, a MEA absorption facility was designed and modelled in Aspen Plus ${ }^{\circledR}$ [32][33][34]. Figure 4 shows the $\mathrm{CO}_{2}$ capture process flowsheet.

Flue gas from the boiler is cooled down to $70{ }^{\circ} \mathrm{C}$ before entering the absorber at the bottom (A2). The solvent is introduced at the top of the column (A9). Reactions take place in the absorber with MEA and $\mathrm{CO}_{2}$ flowing at countercurrent. Vent gas leaves absorber at the top (A10) and a solution of $\mathrm{CO}_{2}$ and aqueous MEA (rich amine solution) leaves the column at the bottom (A3). Then, the temperature of the rich amine solution is increased from 64 to $80{ }^{\circ} \mathrm{C}$ in a heat exchanger (rich/lean exchanger) before entering at the top of the stripper (A11). Steam is required in the MEA regeneration (reboiler) and to separate the solvent and the $\mathrm{CO}_{2}$. Steam reboiler temperature is limited to $120^{\circ} \mathrm{C}$, in order to prevent high MEA degradation rates and corrosion problems. The lean amine solution (A19) leaves stripper at $103{ }^{\circ} \mathrm{C}$ and then goes through the heat exchanger to transfer energy to the rich amine solution flow decreasing temperature down to $87^{\circ} \mathrm{C}$. To achieve a lower temperature before entering again the absorber (A9), an additional cooler is required for reducing solvent temperature to $37^{\circ} \mathrm{C}$. Finally, most of water content in $\mathrm{CO}_{2}$ flow is removed in the condenser and high purity $\mathrm{CO}_{2}$ gas flow leaves flash separator (A14). 


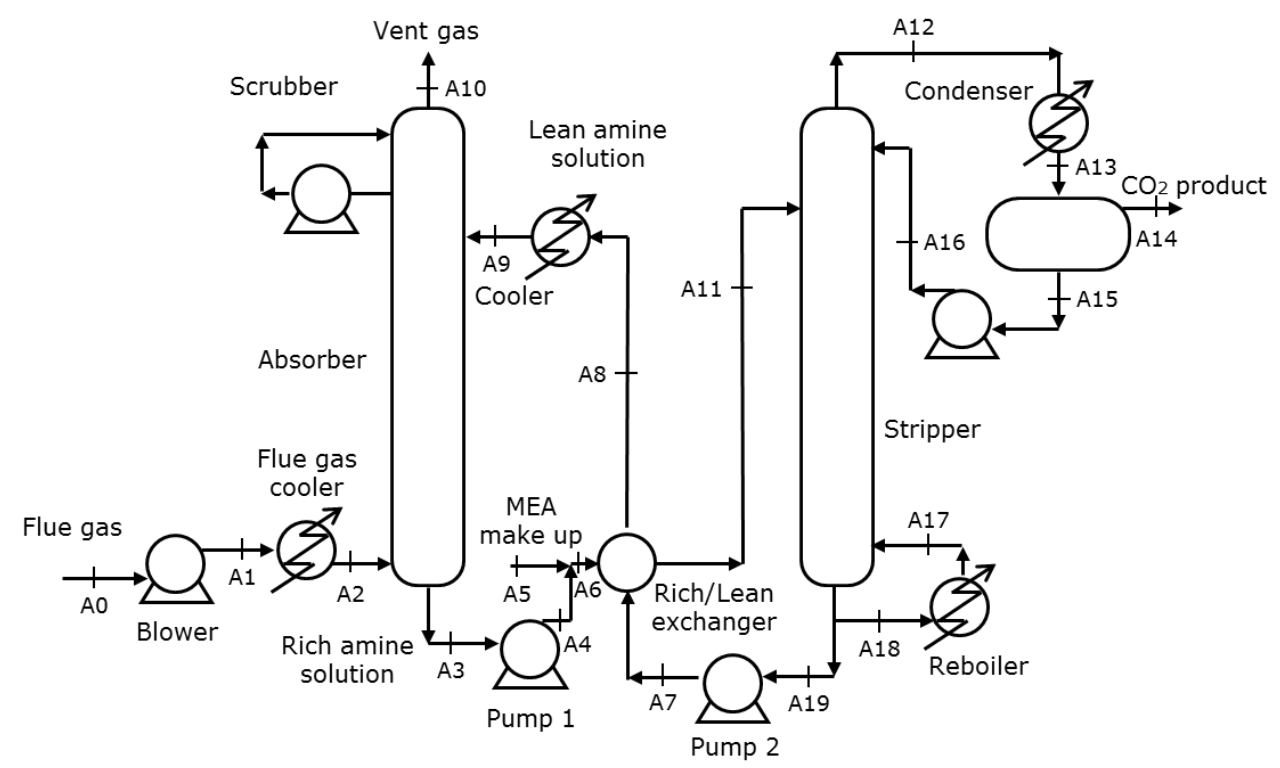

Figure 4. Scheme of the $\mathrm{CO}_{2}$ separating amine plant

The amine plant was modeled in Aspen Plus ${ }^{\circledR}$. Besides operation temperature levels [35], some additional assumptions according to a quite conservative scenario were considered to accurately run the simulations [36][37]:

(i) The MEA weight percentage in the absorption solvent was $20 \%$ wt.

(ii) Stripper was designed to require solvent regeneration energy below $6 \mathrm{GJ} / \mathrm{t}_{\mathrm{CO} 2}$ in any case and to obtain a $\mathrm{CO}_{2}$ flow with a concentration higher than $94 \%$ vol.

(iii) The amine plant columns were sized to capture more than $90 \%$ of $\mathrm{CO}_{2}$ introduced with the flue gas.

(iv) The final facility dimension was set according to methanation plant requirements. These values are collected in following section.

\subsubsection{Methanation plant model}

The proposed methanation scheme is based on TREMP ${ }^{\mathrm{TM}}$ technology [38]. It is composed by three adiabatic reactors at 30 bar, a recycling loop in the first reactor, and an intermediate water condensation after the second stage (Figure 5). Thus, the obtained SNG reaches 95 vol.\% of methane, as the commercial natural gas that can be purchased from the Spanish 
natural gas network [39]. We use adiabatic, catalytic methanation due to its greater scalability and energy integration potential [11].

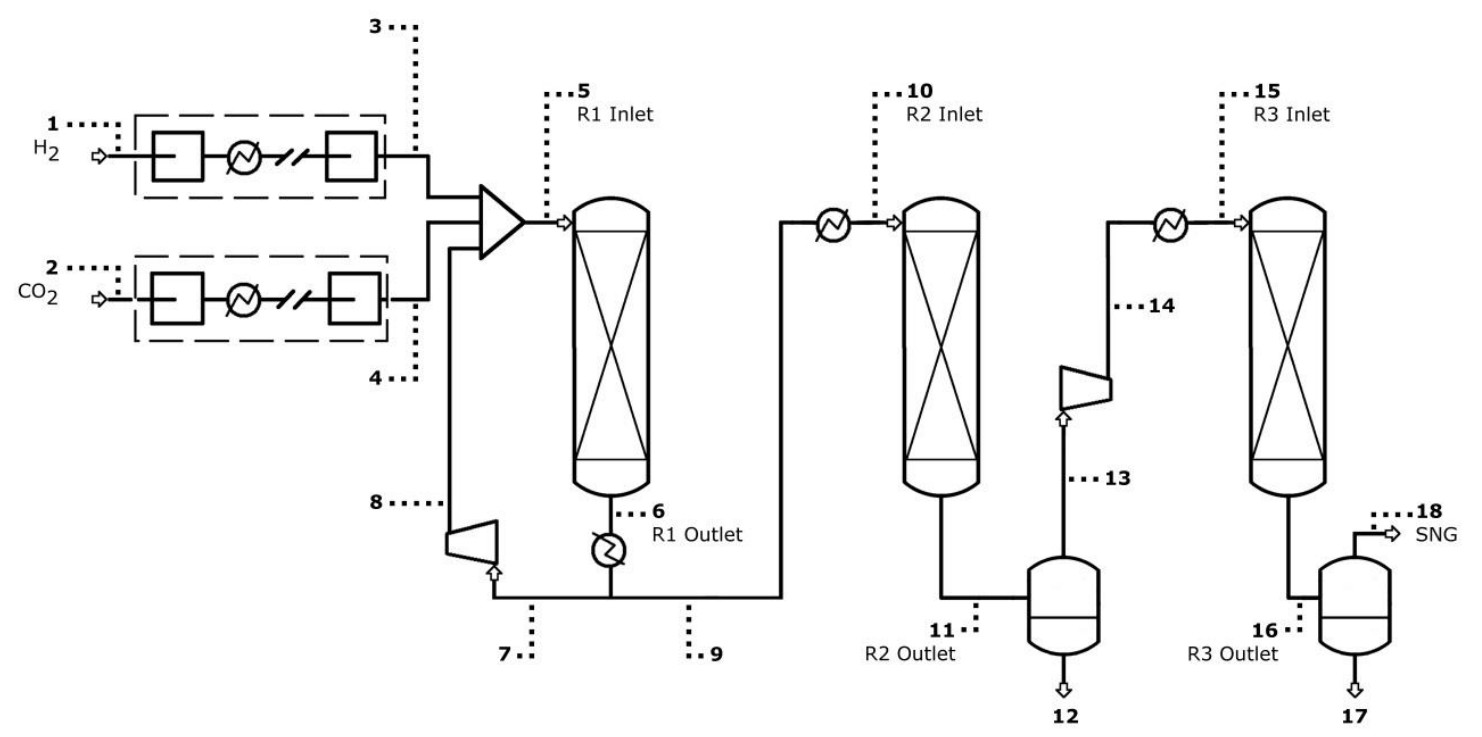

Figure 5. Scheme of the methanation plant.

First, hydrogen (1) and carbon dioxide (2) are pressurized through two multi-stage compressors, what increases the temperature of the gasses up to $300{ }^{\circ} \mathrm{C}$. The outlet gas of Reactor 1 (6) is cooled down to $300{ }^{\circ} \mathrm{C}$ and partially recirculated (72\%) with a blower (8). The temperature of the remaining flow is reduced to $250{ }^{\circ} \mathrm{C}$ prior entering into the next reactor (10). After this second absorption stage (11), water content normally exceeds the 60 vol.\%, what inhibits the reaction; hence, it is reduced to $13 \%$ by condensation (13). Then, the syngas has to be preheated back to $250{ }^{\circ} \mathrm{C}$ for the last methanation stage (15). Last, water content is removed again to achieve the required SNG quality. The plant has been simulated in Aspen Plus ${ }^{\circledR}$ considering pressure drops of 0.3 bar at methanation reactors and 0.6 bar at condensation tanks.

\section{Results}

\section{1 $\mathrm{H}_{2}$ availability and methanation plant size}


The hydrogen and $\mathrm{CO}_{2}$ availabilities (grey area and dashed line in Figure 6, respectively) have been assessed for the year 2014. These graphs are built from the amount of hydrogen known to be available for each type of hour (Section 3.1, Table 2), taking also into account the planned and unplanned shutdowns that the factory reported for each line of production in 2015 (e.g., $1^{\text {st }}$ January). The right axis of Figure 6 is adjusted so that the grey area also indicates the corresponding amount of $\mathrm{CO}_{2}$ required for methanation in each period. Most of the time, the boiler provides enough $\mathrm{CO}_{2}$ to consume the produced hydrogen through methanation (dashed line, Figure 6), although the limited emissions during months like November temporally makes $\mathrm{CO}_{2}$ insufficient at $\mathrm{H}_{2}$ peaks (it occurred 1344 hours during the year 2014).

These lacks of $\mathrm{CO}_{2}$ force to set apart some of the available $\mathrm{H}_{2}$ to maintain the stoichiometry of the methanation reaction. Additionally, there exist periods in which the hydrogen production is too low to reach the minimum operating load of the methanation plant (set at $60 \%$ according to literature [4]), so it must be stopped and none of the resources $\left(\mathrm{CO}_{2}, \mathrm{H}_{2}\right)$ can be consumed. These two issues limit the maximum potential use of $\mathrm{CO}_{2}$ and $\mathrm{H}_{2}$ down to $62.5 \%$ and $91.9 \%$ respectively. This maximum usage, $\alpha_{i}$, is calculated according to Equation 3 , as the sum of the amount that is used in each hour, $v_{i, j}^{\prime}\left[\mathrm{m}^{3}(\mathrm{NTP})\right]$ divided by the sum of the available amount, $v_{i, j}\left[\mathrm{~m}^{3}(\mathrm{NTP})\right]$. The values of $v_{i, j}$ are those presented in Figure 6 (known data), while $V_{H 2, P t G}$ stands for the nominal hourly $\mathrm{H}_{2}$ input of the methanation plant. In the case of the evaluation of the maximum usage, $V_{H 2, P t G}$ is set at $2462.9 \mathrm{~m}^{3}$ (NTP), which is the available $\mathrm{H}_{2}$ when both lines of production operate at P6 (Table 2).

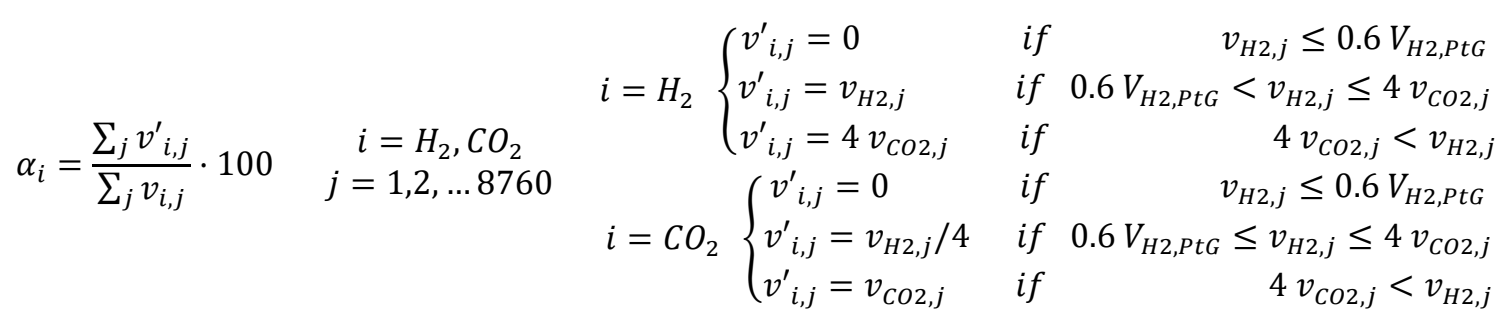




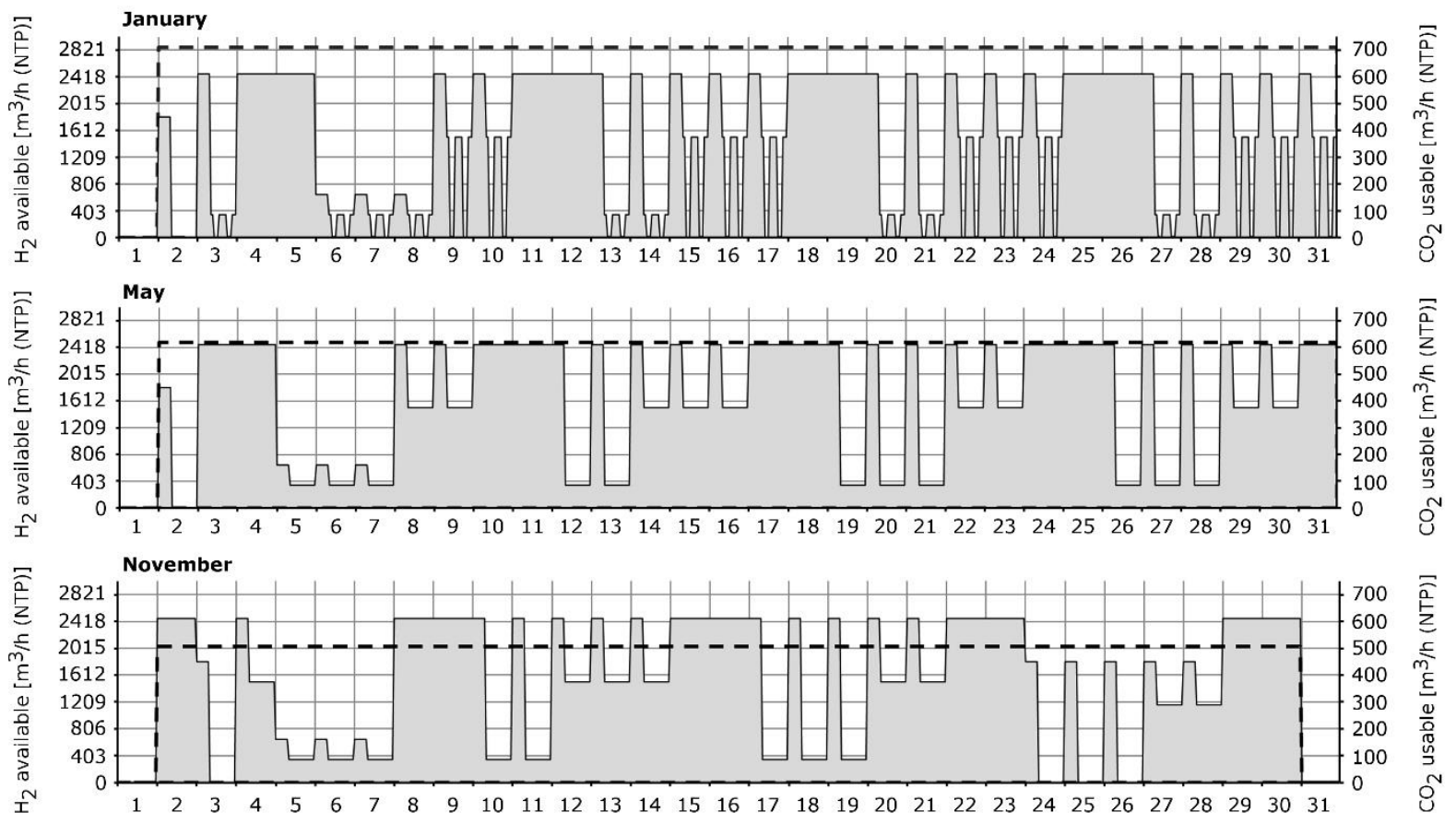

Figure 6. $\mathrm{H}_{2}$ (grey area) and $\mathrm{CO}_{2}$ availabilities (dashed line) for January, May and November.

The size of the hybrid plant was selected taking into account the operating hours (Figure 7) and the percentage of the available $\mathrm{H}_{2}$ that is finally used (Figure 8). We also considered the inclusion of a tank to store the $\mathrm{H}_{2}$, thus softening the intermittent behavior of the resources. The design criteria to size the facility are a minimum of 6000 operating hours and $85 \%$ of $\mathrm{H}_{2}$ utilization, which give the area hold by the dashed line in Figure 7 and 8 . To reduce economic investment on equipment, we select a small $\mathrm{H}_{2}$ buffer of $1000 \mathrm{~m}^{3}$ (NTP) and a methanation plant of $6 \mathrm{MW}_{\mathrm{H} 2}$ input $\left(1998.7 \mathrm{~m}^{3} / \mathrm{h}(\mathrm{NTP})\right)$, which leads to 6070 operating hours per year and a $85.9 \%$ usage of the available hydrogen. The associated amine plant required to fulfill the requirements of methanation has a nominal output of $500 \mathrm{~m}^{3} / \mathrm{h}(\mathrm{NTP})$ of $\mathrm{CO}_{2}$, thus consuming up to the $58.2 \%$ of the $\mathrm{CO}_{2}$ emitted. 


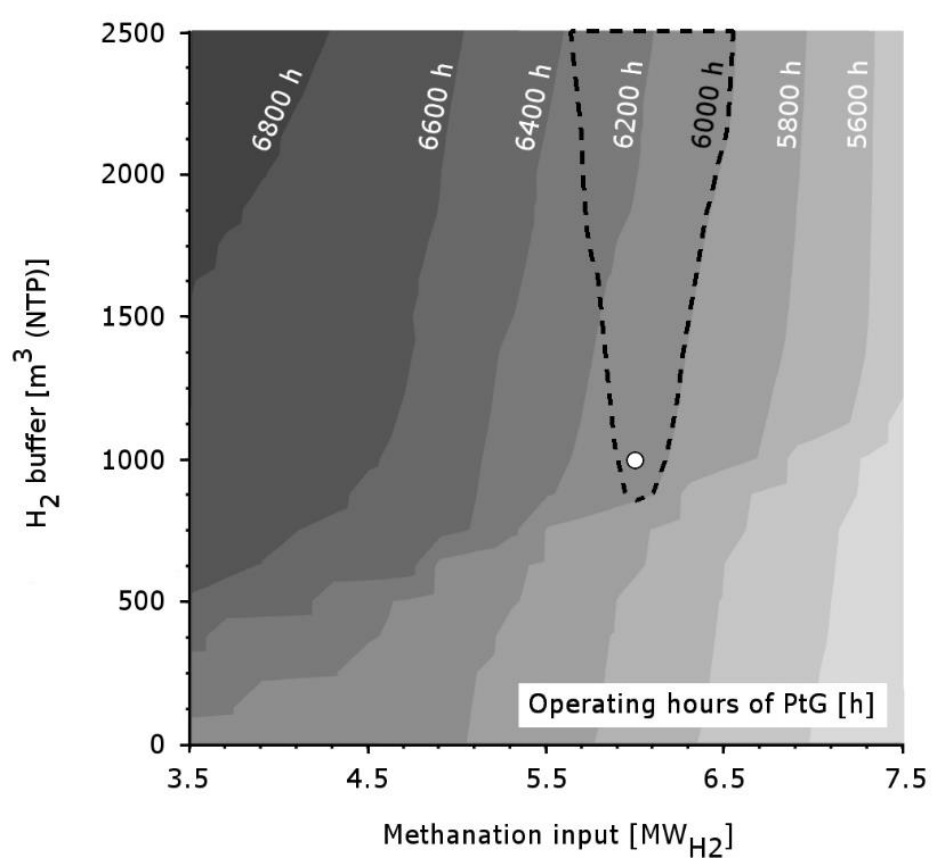

Figure 7. Operating hours as a function of the methanation size and the $\mathrm{H}_{2}$ buffer.

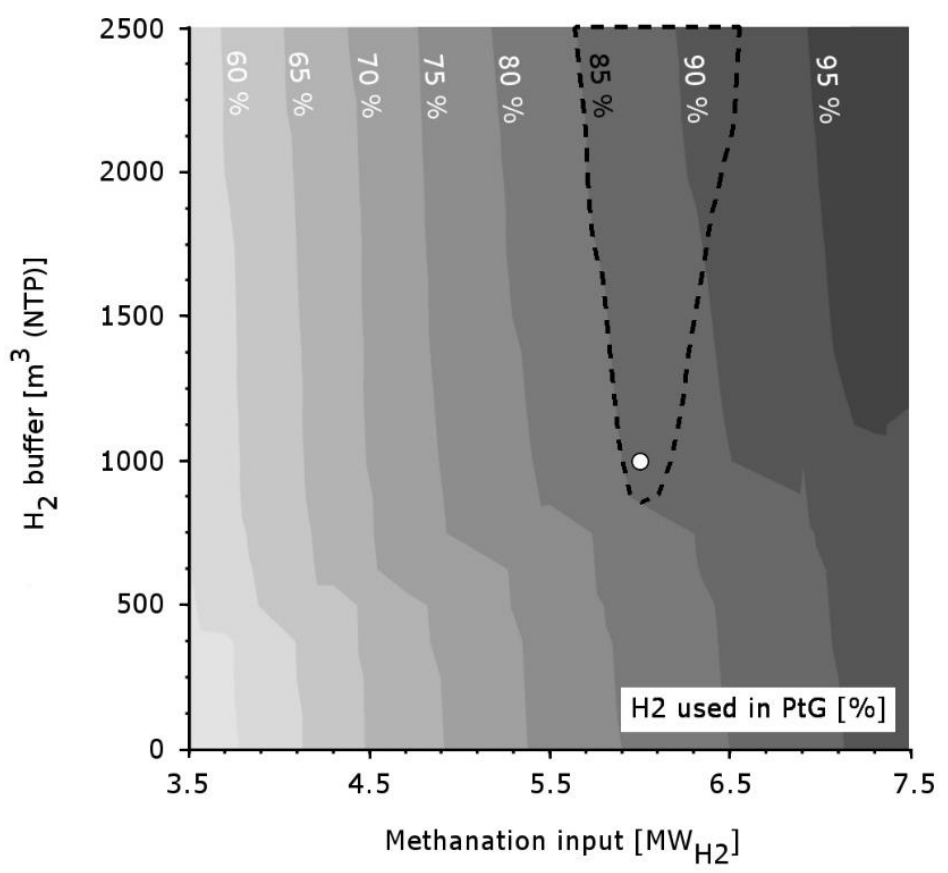

Figure 8. $\mathrm{H}_{2}$ utilization [\%] as a function of the methanation size and the $\mathrm{H}_{2}$ buffer.

The $\mathrm{H}_{2}$ usage presented in figure 8 also follows Equation (3), but in this case $v_{i, j}$ depends on the previous step $v_{i, j-1}$ and $v_{i, j-1}^{\prime}$, since they modify the available $\mathrm{H}_{2}$ in the buffer $v_{B, j}$. It should be noted that the $\mathrm{x}$-axis determines the value of $V_{H 2, P t G}$, and the y-axis sets the value of $v_{B, \max }$. The following rules shall be satisfied: 


$$
\begin{aligned}
& \text { for } i=H_{2}\left\{\begin{aligned}
v_{i, j}^{\prime}=0 & \text { if } & v_{H 2, j}+v_{B, j} \leq 0.6 V_{H 2, P t G} \\
v_{i, j}^{\prime}=v_{H 2, j}+v_{B, j} & \text { if } & 0.6 V_{H 2, P t G}<v_{H 2, j}+v_{B, j} \leq 4 v_{C O 2, j} \\
v_{i, j}^{\prime}=4 v_{C O 2, j} & \text { if } & 4 v_{C O 2, j}<v_{H 2, j}+v_{B, j}
\end{aligned}\right.
\end{aligned}
$$

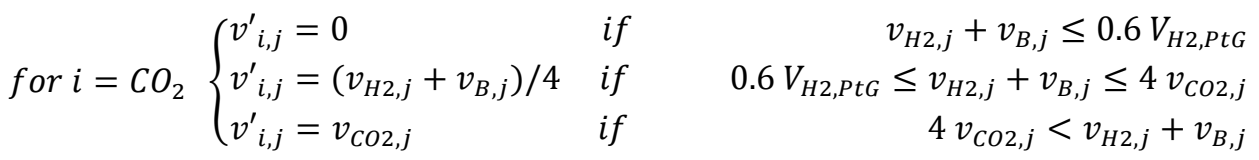

where $v_{B, j}$ depends on the previous step in the following way:

- If the available hydrogen is below the minimum partial load $\left(v_{H 2, j}+v_{B, j} \leq 0.6 V_{H 2, P t G}\right)$, the produced $\mathrm{H}_{2}$ is stored

$$
\left\{\begin{array}{lll}
v_{B, j+1}=v_{B, j}+v_{H 2, j} & \text { if } & v_{B, j}+v_{H 2, j}<v_{B, \max } \\
v_{B, j+1}=v_{B, \text { max }} & \text { if } & v_{B, \max } \leq v_{B, j}+v_{H 2, j}
\end{array}\right.
$$

- If the available carbon dioxide is enough to consume all the hydrogen $\left(0.6 V_{H 2, P t G}<\right.$ $\left.v_{H 2, j}+v_{B, j} \leq 4 v_{C O 2, j}\right)$, the buffer is empty

$$
v_{B, j+1}=0
$$

- If the hydrogen is enough to consume all the carbon dioxide, but it is necessary to use part of the buffered hydrogen $\left(4 v_{C O 2, j}<v_{H 2, j}+v_{B, j}\right)$, the stored $\mathrm{H}_{2}$ will diminish

$$
\left\{\begin{array}{lll}
v_{B, j+1}=v_{B, j}-\left(4 v_{C O 2, j}-v_{H 2, j}\right) & \text { if } & 0<v_{B, j}-\left(4 v_{C O 2, j}-v_{H 2, j}\right) \\
v_{B, j+1}=0 & \text { if } & v_{B, j}-\left(4 v_{C O 2, j}-v_{H 2, j}\right) \leq 0
\end{array}\right.
$$

- If the produced $\mathrm{H}_{2}$ during the hour $\mathrm{j}$ is enough itself to consume all the $\mathrm{CO}_{2}\left(4 v_{c o 2, j}<\right.$ $\left.v_{H 2, j}\right)$, the buffer will store more hydrogen up to its limit

$$
\left\{\begin{array}{lll}
v_{B, j+1}=v_{B, j}+\left(v_{H 2, j}-4 v_{C O 2, j}\right) & \text { if } & v_{B, j}+\left(v_{H 2, j}-4 v_{C O 2, j}\right)<v_{B, \max } \\
v_{B, j+1}=v_{B, \max } & \text { if } & v_{B, \max } \leq v_{B, j}+\left(v_{H 2, j}-4 v_{C O 2, j}\right)
\end{array}\right.
$$

Regarding the operating hours, $\tau$, it is given by Equation 4:

$$
\tau=\frac{\sum_{j} v_{H 2, j}^{\prime}}{V_{H 2, P t G}}
$$

\subsection{PtG-Electrochemical hybrid plant}


Once methanation plant size was defined, the amine plant was designed according to the $\mathrm{CO}_{2}$ requirements $\left(496 \mathrm{~m}^{3} / \mathrm{h}(\mathrm{NTP})\right.$ of $\mathrm{CO}_{2}$ at nominal output). Table 2 shows the main results obtained from the Aspen Plus simulation of the $\mathrm{CO}_{2}$ capture plant.

Table 3. $\mathrm{CO}_{2}$ capture plant simulation results

\begin{tabular}{|c|c|}
\hline \multicolumn{2}{|l|}{ Absorber } \\
\hline Design stages & 14 \\
\hline Pressure (bar) & 1.0 \\
\hline Top stage temperature $\left({ }^{\circ} \mathrm{C}\right)$ & 63.5 \\
\hline Bottom stage temperature $\left({ }^{\circ} \mathrm{C}\right)$ & 64.3 \\
\hline Reflux ratio & 3.9 \\
\hline Boilup ratio & 0.3 \\
\hline \multicolumn{2}{|l|}{ Stripper } \\
\hline Design stages & 14 \\
\hline Pressure (bar) & 1.0 \\
\hline Top stage temperature $\left({ }^{\circ} \mathrm{C}\right)$ & 88.9 \\
\hline Bottom stage temperature $\left({ }^{\circ} \mathrm{C}\right)$ & 102.8 \\
\hline Reflux ratio & 0.4 \\
\hline Boilup ratio & 0.15 \\
\hline Reboiler type & Kettle \\
\hline Thermal energy demand $\left(\mathrm{GJ} / \mathrm{t}_{\mathrm{CO} 2}\right)$ & 5.5 \\
\hline \multicolumn{2}{|l|}{$\mathrm{CO}_{2}$ product characteristics } \\
\hline Temperature $\left({ }^{\circ} \mathrm{C}\right)$ & 34.0 \\
\hline Pressure (bar) & 1.0 \\
\hline Volume flow $\left(\mathrm{m}^{3} / \mathrm{h}(\mathrm{NTP})\right)$ & 524.3 \\
\hline Mass flow $(\mathrm{kg} / \mathrm{h})$ & 997.5 \\
\hline \multicolumn{2}{|l|}{ Mass composition $(\mathrm{kg} / \mathrm{h})$} \\
\hline $\mathrm{CO}_{2}$ & 974.6 \\
\hline $\mathrm{H}_{2} \mathrm{O}$ & 22.8 \\
\hline $\mathrm{O}_{2}$ & 0.002 \\
\hline $\mathrm{N}_{2}$ & 0.087 \\
\hline MEA & - \\
\hline \multicolumn{2}{|l|}{ Mole fraction (\%) } \\
\hline $\mathrm{CO}_{2}$ & 94.6 \\
\hline $\mathrm{H}_{2} \mathrm{O}$ & 5.4 \\
\hline $\mathrm{O}_{2}$ & $3 \mathrm{ppm}$ \\
\hline $\mathrm{N}_{2}$ & $132 \mathrm{ppm}$ \\
\hline MEA & - \\
\hline
\end{tabular}

The $\mathrm{CO}_{2}$ output from the amine plant meets the requirement of the reactors in the methanation plant. A total gas flow of $524.3 \mathrm{~m}^{3} / \mathrm{h}(\mathrm{NTP})$ is produced from the stripper with a composition of 94.6 vol\% $\mathrm{CO}_{2}$ and $5.4 \mathrm{vol} \% \mathrm{H}_{2} \mathrm{O}$. The total auxiliary consumption of the amine plant $(14.2 \mathrm{~kW})$ is much lower than the one in the methanation plant. However, heating and cooling 
demands are significant, especially in the reboiler $(1494.3 \mathrm{~kW})$ and in the additional solvent cooler $(-937.6 \mathrm{~kW})$

The simulated methanation plant produces $518.6 \mathrm{~m}^{3} / \mathrm{h}(\mathrm{NTP})$ of SNG mainly composed by $95.2 \mathrm{vol} \% \mathrm{CH}_{4}$ and 4.1 vol.\% $\mathrm{H}_{2}$ (Table 3). The technical data of SNG show that it can be used in typical applications (LHV of $49.8 \mathrm{MJ} / \mathrm{kg}$, density of $0.694 \mathrm{~kg} / \mathrm{m}^{3}(\mathrm{NTP})$, and Wobbe index of $49.76 \mathrm{MJ} / \mathrm{m}^{3}$ ). Relevant data of temperature, pressure and flows throughout the methanation plant are presented in Table 4.

The total auxiliary consumption of the methanation plant $(513.7 \mathrm{~kW})$ mostly comes from the multi-stage compressors (402.9 $\mathrm{kW}$ for $\mathrm{H}_{2}$, and $105.7 \mathrm{~kW}$ for $\mathrm{CO}_{2}$ ), while blowers' consumption represents less than $1 \%$. Besides, whenever the plant is operating at full load and simultaneously storing $\mathrm{H}_{2}$, the hydrogen compressor could require up to $495.6 \mathrm{~kW}$.

Table 4. Molar compositions [\%] in the methanation plant.

\begin{tabular}{|l|r|r|r|r|r|r|r|r|}
\hline & \multicolumn{1}{|c|}{$\begin{array}{c}\mathbf{H}_{2} \\
\text { Inlet }\end{array}$} & \multicolumn{1}{c|}{$\begin{array}{c}\mathbf{C O}_{2} \\
\text { Inlet }\end{array}$} & \multicolumn{1}{c|}{$\begin{array}{c}\text { R1 } \\
\text { Inlet }\end{array}$} & $\begin{array}{c}\text { R1 } \\
\text { Outlet }\end{array}$ & \multicolumn{1}{c|}{$\begin{array}{c}\text { Outlet } \\
\text { Inlet }\end{array}$} & \multicolumn{1}{c|}{ Outlet } & \\
\hline $\mathrm{CO}_{2}$ & 0.0 & 94.6 & 9.9 & 4.3 & 1.3 & 3.0 & 0.2 & 0.3 \\
\hline $\mathrm{H}_{2}$ & 100.0 & 0.0 & 41.5 & 19.6 & 6.2 & 14.3 & 3.3 & 4.1 \\
\hline $\mathrm{CH}_{4}$ & 0.0 & 0.0 & 15.5 & 24.5 & 30.2 & 69.7 & 76.8 & 95.2 \\
\hline $\mathrm{H}_{2} \mathrm{O}$ & 0.0 & 5.4 & 32.8 & 51.1 & 62.3 & 13.0 & 19.7 & 0.4 \\
\hline $\mathrm{CO}$ & 0.0 & 0.0 & 0.3 & 0.5 & 0.0 & 0.0 & 0.0 & 0.0 \\
\hline
\end{tabular}

Table 5. Temperature, pressure and flows in the methanation plant.

\begin{tabular}{|l|r|r|r|}
\hline Point & $\begin{array}{r}\text { Temperature } \\
{\left[{ }^{\circ} \mathrm{C}\right]}\end{array}$ & $\begin{array}{r}\text { Pressure } \\
{[\mathrm{bar}]}\end{array}$ & $\begin{array}{r}\text { Flow } \\
{\left[\mathrm{m}^{3} / \mathrm{h}(\mathrm{NTP})\right]}\end{array}$ \\
\hline 1 & 25.0 & 1.0 & 1998.7 \\
\hline 2 & 34.0 & 1.0 & 524.3 \\
\hline 3 & 305.2 & 30.0 & 1998.7 \\
\hline 4 & 287.4 & 30.0 & 524.3 \\
\hline 5 & 300.1 & 30.0 & 6879.1 \\
\hline
\end{tabular}




\begin{tabular}{|l|r|r|r|}
\hline 6 & 582.7 & 29.7 & 6050.3 \\
\hline 7 & 300.0 & 29.7 & 4356.2 \\
\hline 8 & 301.7 & 30.0 & 4356.2 \\
\hline 9 & 300.0 & 29.7 & 1694.1 \\
\hline 10 & 250.0 & 29.7 & 1694.1 \\
\hline 11 & 414.1 & 29.4 & 1572.2 \\
\hline 12 & 136.1 & 28.8 & 891.0 \\
\hline 13 & 136.1 & 28.8 & 681.2 \\
\hline 14 & 141.1 & 30.0 & 681.2 \\
\hline 15 & 250.0 & 30.0 & 681.2 \\
\hline 16 & 358.0 & 29.7 & 643.2 \\
\hline 17 & 40.0 & 29.1 & 124.5 \\
\hline 18 & 40.0 & 29.1 & 518.6 \\
\hline
\end{tabular}

The overall cooling and heating needs of the hybrid plant (methanation/carbon capture) are $3675.3 \mathrm{~kW}$ and $1533.7 \mathrm{~kW}$, respectively (Table 5). Most of the heat requirement takes places during the desorption stage of the captured $\mathrm{CO}_{2}$ in the amine plant. Nevertheless, this external heating demand can be suppressed by integrating the streams of both systems (Figure 9, empty-dot exchangers), what concurrently diminishes the cooling needs down to $2141.6 \mathrm{~kW}$. Moreover, there are remaining cooling necessities with high temperature level (R1 outlet), that allows producing $238.8 \mathrm{~kg} / \mathrm{h}$ of steam at $180{ }^{\circ} \mathrm{C}$ for the electrochemical plant; the remainder energy can be cooled with water since the temperatures to reach are not lower than $34{ }^{\circ} \mathrm{C}$ (Figure 9, solid-dot exchangers). The minimum temperature difference between hot and cold streams for the design of the exchanger network is $10^{\circ} \mathrm{C}$.

Table 6. Streams of the Pinch Analysis.

\begin{tabular}{|c|c|c|c|c|}
\hline & Stream & $\mathrm{T}_{\mathrm{i}}\left[{ }^{\circ} \mathrm{C}\right]$ & $\mathrm{T}_{\mathrm{f}}\left[{ }^{\circ} \mathrm{C}\right]$ & $\Delta \mathrm{Q}[\mathrm{kW}]$ \\
\hline \multicolumn{5}{|l|}{ Amine capture plant } \\
\hline Solvent cooler (A8) & Hot & 85.0 & 37.8 & -937.6 \\
\hline Gas cooler (A1) & Hot & 175.0 & 70.0 & -238.0 \\
\hline Stripper condenser & Hot & 88.9 & 88.7 & -270.4 \\
\hline Flash unit (A13) & Hot & 89.0 & 34.0 & -443.8 \\
\hline Reboiler & Cold & 120.0 & 120.5 & 1494.3 \\
\hline
\end{tabular}




\begin{tabular}{|l|r|r|r|r|}
\hline \multicolumn{5}{|l|}{ Methanation plant } \\
\hline R1 outlet (6) & Hot & 582.7 & 300.0 & -920.9 \\
\hline R2 inlet (9) & Hot & 300.0 & 250.0 & -42.6 \\
\hline R2 outlet (11) & Hot & 414.1 & 136.1 & -645.5 \\
\hline R3 inlet (14) & Cold & 141.1 & 250.0 & 39.4 \\
\hline R3 outlet (16) & Hot & 358.1 & 40.0 & -176.5 \\
\hline Electrochemical plant & Cold & 20.0 & 25.0 & 1939.2 \\
\hline Cold water & Cold & 50.0 & 180.0 & 202.4 \\
\hline Steam & & &
\end{tabular}

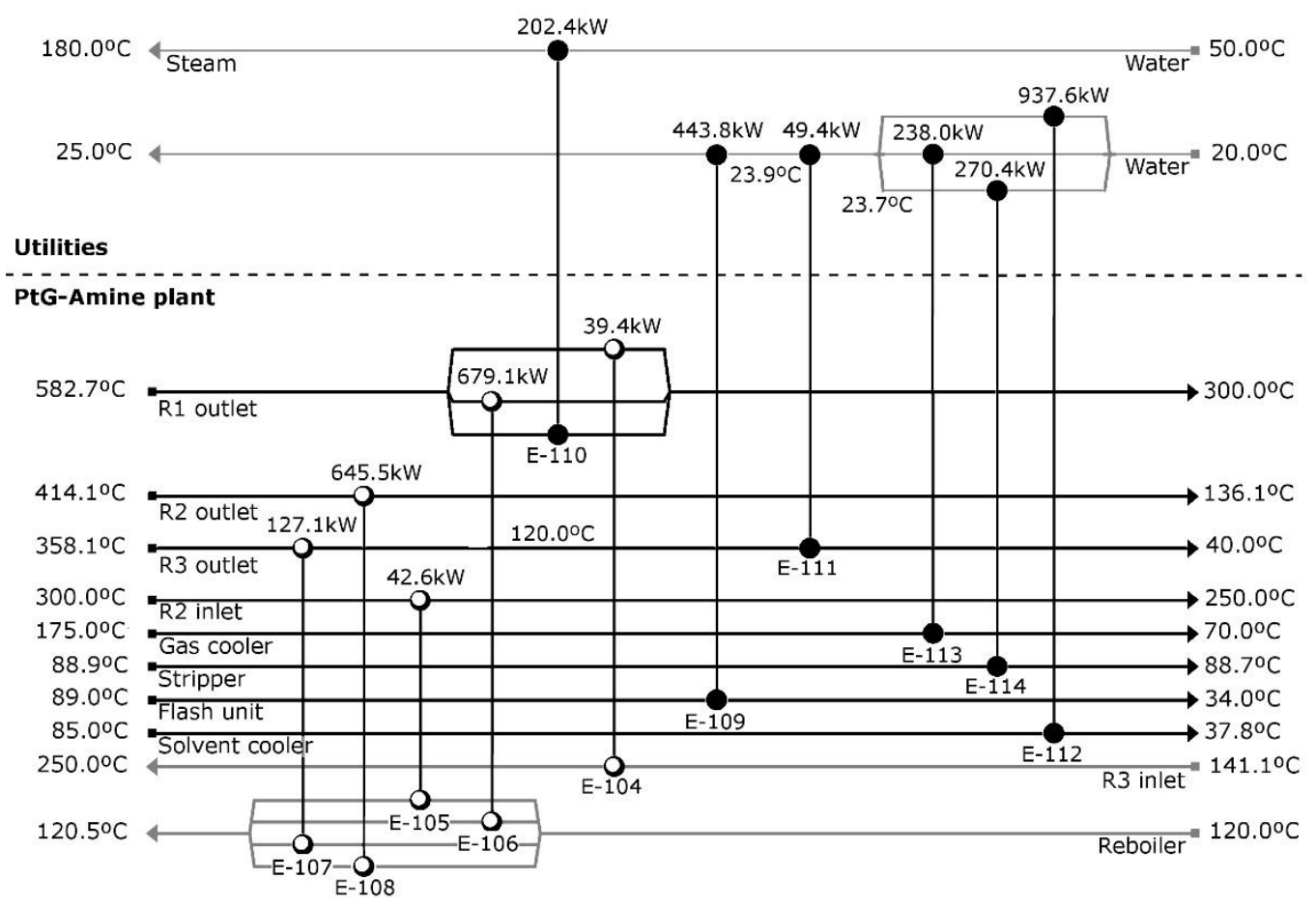

Figure 9. Optimized heat exchanger network (Black lines - Hot streams, Grey lines - Cold streams).

\subsection{Economic analysis}

To accomplish the economic analysis of the whole facility, the costs of the main equipment for the three processes were obtained: the amine plant, the methanation plant and the optimized heat exchanger network. Then, total capital investment (CAPEX) was completed including other direct and indirect costs as a percentage of the total purchased equipment. Operating cost (OPEX) includes the production costs, which consist of the O\&M, electricity, 
cooling water, MEA and catalyst renovation. Regarding the economic incomes, two concepts were considered: the Natural Gas (NG) and the additional medium pressure (MP) steam produced in the optimized HEN. This steam is used in the electrochemical industry and hence, can be considered as an input from the network. Meanwhile, natural gas is used in the boiler of the electrochemical plant in order to avoid its purchase from external companies (the selling price would be lower than the purchase price, so thus the income is maximized). The NG price was obtained according to the market $(28.99 € / \mathrm{MWh})$ and the MP steam price was obtained as the NG saving for its generation in conventional gas fired boilers in the baseline scenario (24.64 $€ / t)$. Table 6 shows the complete CAPEX and OPEX of the PtG-Electrochemical hybrid plant and the total year incomes of the facility. Some costs regarding the amine plant were included in the HEN disaggregated costs in order not to duplicate equipment costs. Solvent cooler, gas cooler and reflux condenser cooling needs are covered with cooling water and heat exchangers are already included in the HEN (E-112, E-113 and E-114)

Table 7. CAPEX, OPEX and year incomes for the PtG-Electrochemical hybrid plant.

\begin{tabular}{|c|c|c|c|c|}
\hline \multicolumn{5}{|l|}{ CAPEX } \\
\hline \multicolumn{5}{|l|}{ Direct costs } \\
\hline \multicolumn{5}{|c|}{ Equipment costs } \\
\hline Reference & Equipment / Process & Cost $(€)$ & Parameter, A & Cost equation $(€)$ \\
\hline \multicolumn{5}{|c|}{ CO2 capture amine plant (Total cost, $523486 €$ ) } \\
\hline [40] & Amine plant & 523486 & $\mathrm{CO} 2$ captured $(\mathrm{t} / \mathrm{h})$ & $26.094 \cdot 10^{6} \cdot(\mathrm{A} / 408)^{0.65}$ \\
\hline \multicolumn{5}{|c|}{ Methanation plant (Total cost, $2158644 €$ ) } \\
\hline \multirow{4}{*}{ [41] } & H2 compressor & 286978 & \multirow{4}{*}{ Power (kW) } & \multirow{4}{*}{$26.7 \cdot 10^{4} \cdot(\mathrm{A} / 445)^{0.67}$} \\
\hline & CO2 compressor & 101916 & & \\
\hline & Recirculation blower & 10390 & & \\
\hline & Blower & 6150 & & \\
\hline [42] & Reactors & 1660500 & SNG Power $(\mathrm{kW})$ & $300 \cdot \mathrm{A}$ \\
\hline [43] & H2 storage tank & 50614 & H2 (kg, 30bar) & $563 \cdot \mathrm{A}$ \\
\hline [41] & Catalyst & 42097 & Catalyst $\left(\mathrm{m}^{3}\right)$ & $187500 \cdot \mathrm{A}$ \\
\hline \multicolumn{5}{|c|}{ HEN (Total cost, $179642 €)$} \\
\hline \multirow{9}{*}{$\begin{array}{l}\text { Simulation } \\
\text { Model }\end{array}$} & E-108 & 22992 & \multirow{9}{*}{ Area $\left(\mathrm{m}^{2}\right)$} & \multirow{9}{*}{ Aspen Energy Analyzer } \\
\hline & E-113 & 45716 & & \\
\hline & E-109 & 13459 & & \\
\hline & E-114 & 9912 & & \\
\hline & E-112 & 14981 & & \\
\hline & E-104 & 10546 & & \\
\hline & E-106 & 14894 & & \\
\hline & E-110 & 11276 & & \\
\hline & E-111 & 11822 & & \\
\hline
\end{tabular}




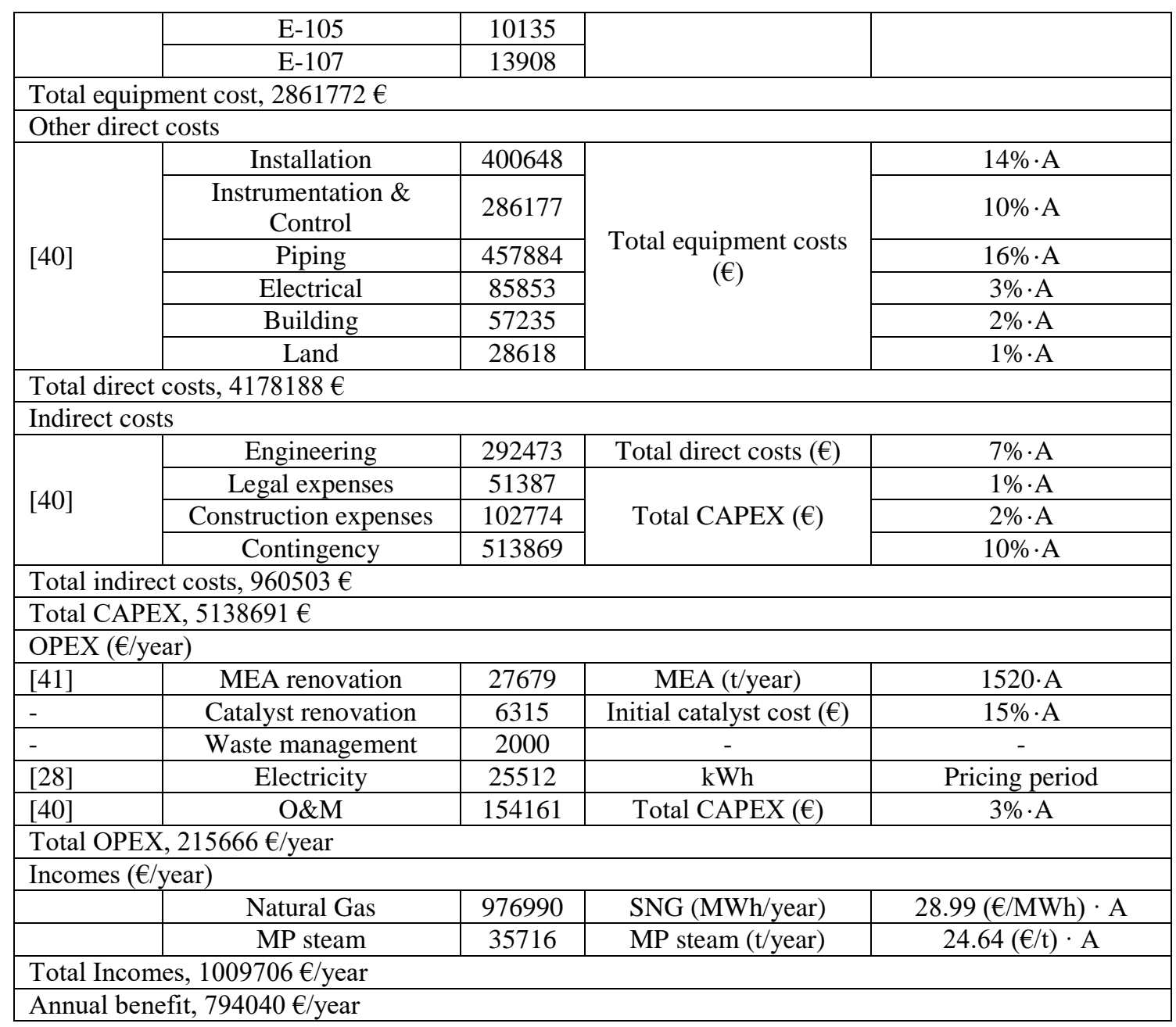

Considering previous values, total CAPEX of the facility is $5.13 \mathrm{M} €$, of which $56 \%$ correspond with the cost of the equipment. OPEX is about $0.216 \mathrm{M} € /$ year and total incomes are $1 \mathrm{M} €$ /year. To obtain the Net Present Value (NPV), the Internal Rate of Return (IRR) and the Pay-back (PB) of the investment, a 5\% discount rate and a 20 years lifetime were considered. Table 7 shows the economic results for the base case and for different discount rates.

Table 8. PB, IRR and NPV evaluation for different discount rate

\begin{tabular}{|c|c|c|c|}
\hline $\begin{array}{c}\text { Discount } \\
\text { rate }\end{array}$ & PB (years) & IRR (\%) & NPV (M€) \\
\hline $3.0 \%$ & 7.3 & 11.07 & 6.68 \\
\hline $4.0 \%$ & 7.6 & 10.00 & 5.65 \\
\hline $5.0 \%$ & 8.0 & 8.96 & 4.76 \\
\hline $6.0 \%$ & 8.4 & 7.93 & 3.97 \\
\hline
\end{tabular}




\begin{tabular}{|l|l|l|l|}
\hline $7.0 \%$ & 8.9 & 6.92 & 3.27 \\
\hline
\end{tabular}

Economic analysis shows positive values that can make attractive the PtG-Electrochemical plant erection. Analyzing the base case scenario (5\% of discount rate) it can be observed that capital investment will be recovered in 8 years, generating a 4.8 M€ NPV at the end of the project lifetime with an IRR of $9 \%$. Hence, the present case study avoids the requirement of subsidies to be economically feasible, contrarily to similar PtG research projects that can be found in literature [11]. This is mainly because the $\mathrm{H}_{2}$ is available in the own industry and no additional water electrolyzers are required. Normally, water electrolyzer represents the highest cost in a PtG facility and it makes very difficult to recover capital investment in a reasonable period of time. Furthermore, the size of the current facility has been carefully chosen after a previous complete analysis of the different processes and taking into account the input gas flows to the methanation plant. In order to extend the economic study, some sensitivity analyses have been performed. Two main parameters were analyzed due to their significant influence on the final revenues of the project: $\mathrm{NG}$ price and $\mathrm{CO}_{2}$ credit price. Firstly, NG price is usually quite unstable and its final value depends on the oil and gas market. In addition, final use of the SNG can be also influenced on the sale price (e.g., transport, gas-fired facilities, NG national network). Regarding $\mathrm{CO}_{2}$ credit price, there also exists a high uncertainty. Actually, no $\mathrm{CO}_{2}$ credit revenue has been considered in this study since this particular industry does not have to pay for its emissions. However, if we consider that SNG is fired in the boilers of the chemical facility, $\mathrm{CO}_{2}$ is always in a loop. It is not emitted since produced $\mathrm{CO}_{2}$ is the same that is captured and used for SNG production.

In addition, electricity price variation will also have an influence on the cost analysis, especially a change in the pricing system because it will modify not only the OPEX but also the operation hours of the hybrid plant since they directly depend on the billing periods. In 
any case, this kind of chemical plants based on electrolyzers follow the same operational procedure and their production depends on the electricity price, working at nominal load when electricity prices are low and diminishing production when electricity prices are higher. This pattern is perfectly adapted to the hybrid concept since it also takes advantage of the lower electricity prices periods when the largest by-production of hydrogen occurs.
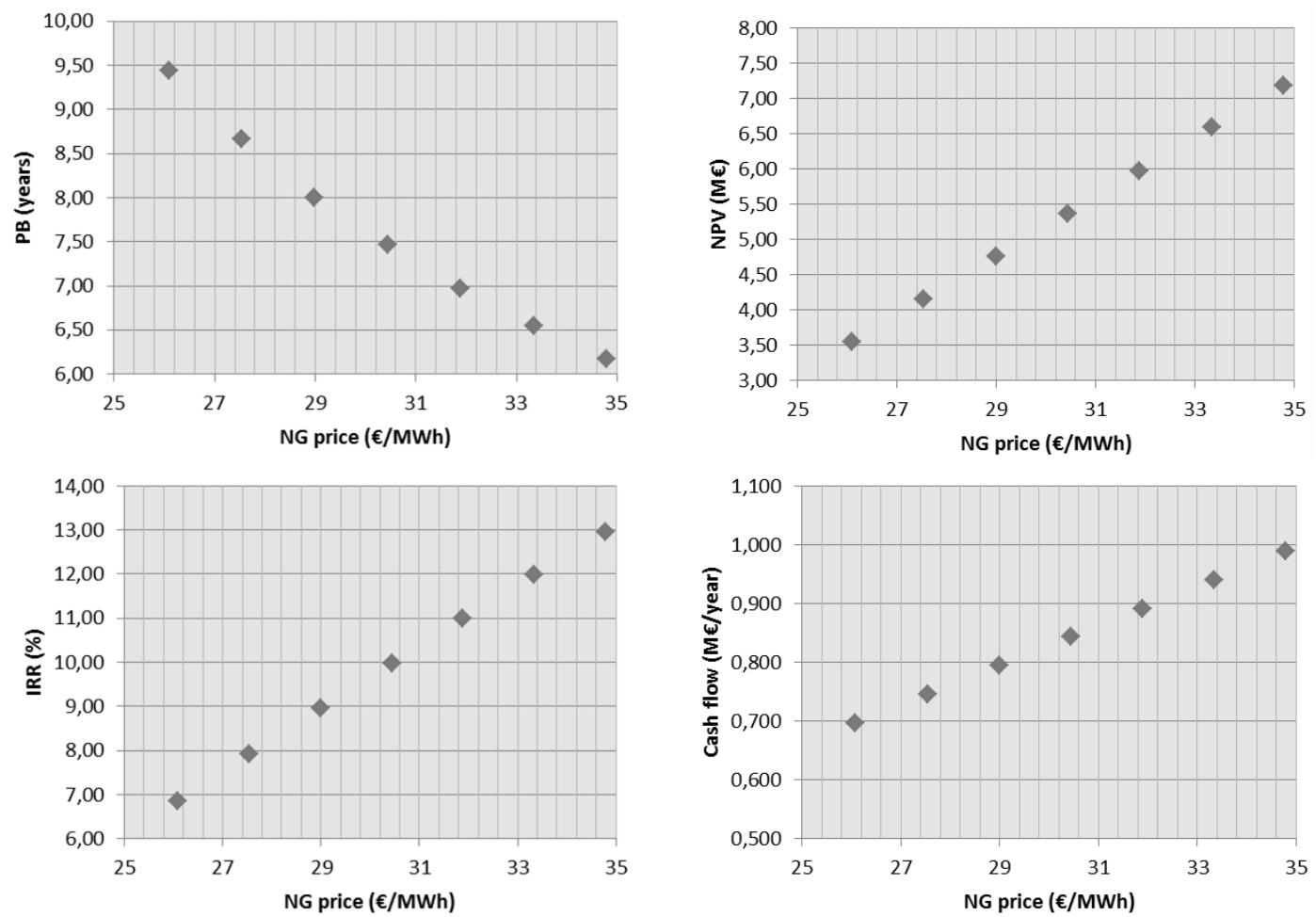

Figure 10. NG price influence on economic parameters 

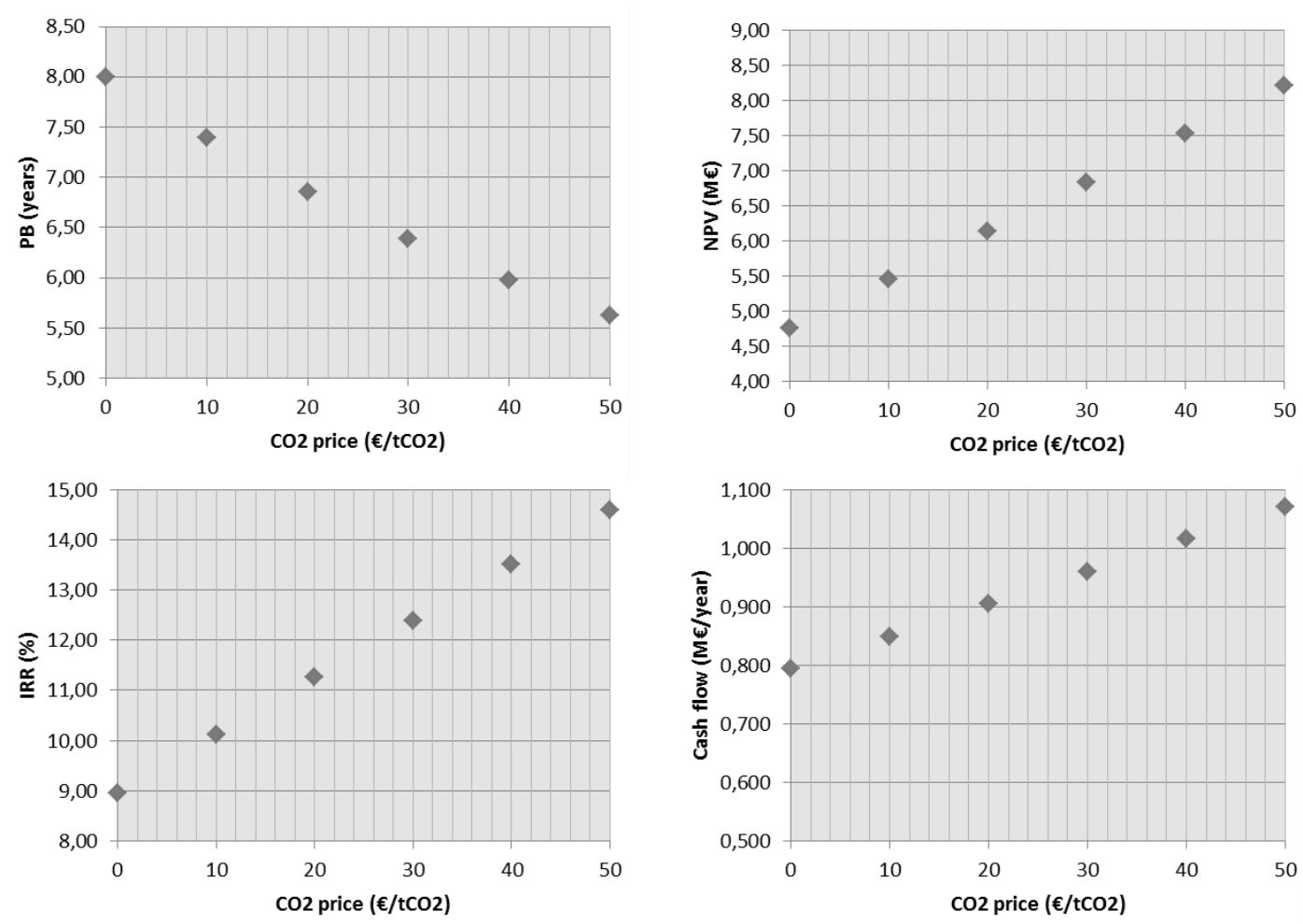

Figure 11. $\mathrm{CO}_{2}$ credit price influence on economic parameters

Figure 10 and Figure 11 show the influence on economic parameters of both, NG price and $\mathrm{CO}_{2}$ credit price. The higher NG price is, the more profitable is the investment. It is difficult to predict the evolution of oil and gas fuels, but it is expected a future rise of their prices. For instance, a $15 \%$ increase of NG price (from 29 to $33.3 € / \mathrm{MWh}$ ) would increase IRR up to $12 \%$ with a PB of 6 years and a half achieving very remarkable results for this kind of projects. The case regarding $\mathrm{CO}_{2}$ credit price is more complex. The lack of a clear regulation or definitive taxes for these singular facilities make difficult to establish a future price. Nevertheless, $30 € / t_{\mathrm{CO} 2}$ is a reasonable value for making competitive the most $\mathrm{CO}_{2}$ capture technologies. With this $\mathrm{CO}_{2}$ credit price, $\mathrm{PB}$ is reduced below 6 years and a half and IRR is increased up to $12.4 \%$.

\section{Conclusions}


We have proposed a novel PtG-Electrochemical hybrid plant that incorporates methanation as a new chemical line of production, thus rising in value substantial amounts of available byproduct hydrogen, and consuming $\mathrm{CO}_{2}$ emissions from its own gas-fired boilers. The preliminary analysis shows that the products yielding lower profits, like ammonia, are the most suitable to be substituted. The analysis has been carried out using real operating data of an electrochemical factory.

This work shows that PtG-Electrochemical hybrid plant is technical and economically feasible. The plant can be running more than 6000 hours per year consuming more than the $85 \%$ of available hydrogen and almost $60 \%$ of the $\mathrm{CO}_{2}$ emitted by the chemical industry. The hybrid plant can achieve a production of $518.5 \mathrm{~m}^{3} / \mathrm{h}$ (NTP) of SNG and additionally $238 \mathrm{~kg} / \mathrm{h}$ of MP steam that are used in the industry itself. Since no additional water electrolyzers and consequently, no further electricity consumption is required, economic analysis yield very remarkable figures. Analyzing the base case scenario (5\% discount rate) it can be observed that capital investment will be recovered in 8 years, generating a $4.8 \mathrm{M} €$ NPV at the end of the project lifetime with an IRR of $9 \%$. Moreover, sensitivity analyses have also shown that these values can be even better if $\mathrm{CO}_{2}$ credit price or NG price increase in a near term.

Although this is a particular case study, some conclusions can be generalized with the aim of speeding up the deployment of PtG at industrial scale. The present PtG-Electrochemical hybrid technology can overcome the economic barriers of erecting a commercial plant, thus allowing gaining operational experience concerning methanation reactors and their performance with variable $\mathrm{H}_{2}$ and $\mathrm{CO}_{2}$ flows. In addition, it is expected that equipment cost can be reduced in a future and this reduction could be achieved faster with more industrial scale facilities.

\section{Acknowledgements}


This research is funded by the Department of Industry and Innovation of Gobierno de Aragón through the program "Ayudas Innovaragón 2014”. Financial support for M. Bailera during his Ph.D. studies was co-funded by the Department of Industry and Innovation of Diputación General de Aragón, and by the European Social Fund.

\section{Nomenclature}

\begin{tabular}{|l|l|l|}
\hline Variable & Units & Description \\
\hline$\alpha_{i}$ & $\%$ & Usage of resource $\mathrm{i}$ \\
\hline$v_{B, j}$ & $m^{3}(\mathrm{NTP})$ & Amount of $\mathrm{H}_{2}$ that is present in the buffer at the beginning of hour $\mathrm{j}$ \\
\hline$v_{B, \text { max }}$ & $m^{3}(\mathrm{NTP})$ & Maximum capacity of the $\mathrm{H}_{2}$ buffer \\
\hline$v_{i, j}$ & $m^{3}(\mathrm{NTP})$ & Available amount of resource $\mathrm{i}$ at hour $\mathrm{j}$ \\
\hline$v_{i, j}^{\prime}$ & $m^{3}(\mathrm{NTP})$ & Used amount of resource $\mathrm{i}$ at hour $\mathrm{j}$ \\
\hline$V_{H 2, \text { PtG }}$ & $m^{3}(\mathrm{NTP})$ & Nominal hourly input of the methanation plant \\
\hline$\dot{V}_{H 2, \text { ammonia }}$ & $m^{3} \cdot h^{-1}(\mathrm{NTP})$ & $\mathrm{H}_{2}$ by-production destined to ammonia line \\
\hline$\dot{V}_{H 2}$ & $m^{3} \cdot h^{-1}(\mathrm{NTP})$ & $\mathrm{H}_{2}$ by-production \\
\hline$\eta$ & & Efficiency of the electrolysis \\
\hline$\tau$ & $h$ & Operating hours of the methanation plant \\
\hline NPV & $€$ & Net Present Value \\
\hline IRR & $\%$ & Internal Rate of Return \\
\hline PB & years & Pay-back \\
\hline
\end{tabular}

\section{References}

[1] European Parliament. Directive 2009/28/EC of the European Parliament and of the Council of 23 April 2009. 2009.

[2] Capros P, Vita A De, Tasios N, Siskos P, Kannavou M, Petropoulos A, et al. EU Reference Scenario 2016: Energy, transport and GHG emissions. Trends to 2050. European Union; 2016. doi:10.2833/9127.

[3] Pierre I, Bauer F, Blasko R, Dahlback N, Dumpelmann M, Kainurinne K, et al. Flexible generation: Backing up renewables. 2011.

[4] Götz M, Lefebvre J, Mörs F, McDaniel Koch A, Graf F, Bajohr S, et al. Renewable 
Power-to-Gas: A technological and economic review. Renew Energy 2016;85:137190.

[5] Rönsch S, Schneider J, Matthischke S, Schlüter M, Götz M, Lefebvre J, et al. Review on methanation - From fundamentals to current projects. Fuel 2016;166:276-96.

[6] Streibel M, Nakaten N, Kempka T, Kühn M. Analysis of an integrated carbon cycle for storage of renewables. Energy Procedia 2013;40:202-11. doi:10.1016/j.egypro.2013.08.024.

[7] Kühn M, Nakaten N, Streibel M, Kempka T. CO2 geological storage and utilization for a carbon neutral "power-to-gas-to-power" cycle to even out fluctuations of renewable energy provision. Energy Procedia 2014;63:8044-9. doi:10.1016/j.egypro.2014.11.841.

[8] Bailera M, Lisbona P, Romeo LM, Espatolero S. Power to Gas-biomass oxycombustion hybrid system: Energy integration and potential applications. Appl Energy 2016;167:221-9. doi:10.1016/j.apenergy.2015.10.014.

[9] Sterner M. Bioenergy and renewable power methane in integrated 100\% renewable energy systems. Kassel university press GmbH, 2009.

[10] Thrän D, Billing E, Persson T, Svensson M, Daniel-Gromke J, Ponitka J, et al. Biomethane. Status and Factors Affecting Market Development and Trade. 2014.

[11] Bailera M, Lisbona P, Romeo LM, Espatolero S. Power to Gas projects review: Lab, pilot and demo plants for storing renewable energy and CO2. Renew Sustain Energy Rev 2017;69:292-312. doi:10.1016/j.rser.2016.11.130.

[12] Hofstetter D. Biocatalytic Methanation with Methanogenic Archaea for Power-to-Gas Energy Storage. Biomass Swiss Energy Futur. Conf. 2014, 2014. 
[13] BioCat Project is still operating at full speed 2015. http://biocatproject.com/news/biocat-project-is-still-operating-at-full-speed/ (accessed August 31, 2015).

[14] Hofstetter D. The BioCat Project - Lifting Biological Methanation to Market Readiness. REGATEC 2015, Barcelona, Spain: 2015.

[15] Adamsen APS. Three innovative methanation technologies - Aarhus University. Work. Promot. biomethane Denmarkm, Aarhus University; 2013.

[16] Engvall K. Bio-SNG produced in a PtG and biomass gasification system. Green Gas Res. Outlook Sweden, Sweden: Energiforsk; 2015.

[17] Landgraf M. Flexible Methane Production from Electricity and Bio-mass. Press Release - Karlsruhe Inst Technol 2014.

[18] Benjaminsson G, Benjaminsson J, Boogh Rudberg R. Power-to-Gas - A technical review. 2013.

[19] Köbler J. Balanced mobility. Encount - Audi Technol Mag 2011:36-41.

[20] Otten R. The first industrial PtG plant - Audi e-gas as driver for the energy turnaround. CEDEC Gas Day 2014, Verona, Italy: 2014.

[21] Strohbach O. Audi e-gas plant stabilizes electrical grid. Press Release - Audi MediaInfo - Technol Innov Commun 2015.

[22] Forschungsjahrbuch Erneuerbare Energien 2012 - Forschungsberichte im Überblick. Bundesministerium für Umwelt, Naturschutz und Reaktorsicherheit; 2012.

[23] Rieke S. Power-to-Gas technology - the missing link in renewable energy systems. Ecosummit, Berlin, Germany: 2012. 
[24] Bailera M, Lisbona P, Romeo LM. Power to gas-oxyfuel boiler hybrid systems. Int J Hydrogen Energy 2015;40:10168-75. doi:10.1016/j.ijhydene.2015.06.074.

[25] Bailera M, Kezibri N, Romeo LM, Espatolero S, Lisbona P, Bouallou C. Future applications of hydrogen production and $\mathrm{CO} 2$ utilization for energy storage: Hybrid Power to Gas-Oxycombustion power plants. Int J Hydrogen Energy 2017:1-8. doi:10.1016/j.ijhydene.2017.02.123.

[26] Quadrelli EA, Centi G, Duplan JL, Perathoner S. Carbon dioxide recycling: Emerging large-scale technologies with industrial potential. ChemSusChem 2011;4:1194-215. doi:10.1002/cssc.201100473.

[27] Wang Y, Kowal J, Leuthold M, Sauer DU. Storage system of renewable energy generated hydrogen for chemical industry. Energy Procedia 2012;29:657-67. doi:10.1016/j.egypro.2012.09.076.

[28] ORDEN ITC/2794/2007, de 27 de septiembre, por la que se revisan las tarifas eléctricas a partir del 1 de octubre de 2007. BOE 2007;234:39690-8.

[29] Orden IET/2444/2014, de 19 de diciembre, por la que se determinan los peajes de acceso de energía eléctrica para 2015. 2014.

[30] Hohmann, Edward Charles J. Optimum networks for heat exchange (Thesis). University of Southern California, 1971.

[31] Linnhoff B, Flower JR. Synthesis of heat exchanger networks: I. Systematic generation of energy optimal networks. II. Evolutionary generation of networks with various criteria of optimality. AIChE J 1978;24:633-54.

[32] Alie CF. CO2 Capture With MEA: Integrating the Absorption Process and Steam 
Cycle of an Existing Coal-Fired Power Plant. 2004.

[33] Alie C, Backham L, Croiset E, Douglas PL. Simulation of CO2 capture using MEA scrubbing: A flowsheet decomposition method. Energy Convers Manag 2005;46:47587. doi:10.1016/j.enconman.2004.03.003.

[34] Erfani A, Boroojerdi S, Dehghani A. Simulation of an operational amine based CO2 removal plant as an example of $\mathrm{CO} 2$ capture at coal-fired power plants. Pet Coal 2015;57:85-92.

[35] Abu-Zahra MRM, Schneiders LHJ, Niederer JPM, Feron PHM, Versteeg GF. CO2 capture from power plants. Part I. A parametric study of the technical performance based on monoethanolamine. Int J Greenh Gas Control 2007;1:37-46. doi:10.1016/S1750-5836(06)00007-7.

[36] Zhang W, Liu H, Sun Y, Cakstins J, Sun C, Snape CE. Parametric study on the regeneration heat requirement of an amine-based solid adsorbent process for postcombustion carbon capture. Appl Energy 2016;168:394-405. doi:10.1016/j.apenergy.2016.01.049.

[37] Shakerian F, Kim KH, Szulejko JE, Park JW. A comparative review between amines and ammonia as sorptive media for post-combustion CO2 capture. Appl Energy 2015;148:10-22. doi:10.1016/j.apenergy.2015.03.026.

[38] Kopyscinski J, Schildhauer TJ, Biollaz SMA. Production of synthetic natural gas (SNG) from coal and dry biomass - A technology review from 1950 to 2009. Fuel 2010;89:1763-83.

[39] BOE-A-2013-185. Resolución de 21 de diciembre de 2012, de la Dirección General de Política Energética y Minas, por la que se modifica el protocolo de detalle PD-01. 
Ministerio de Industria, Energía y Turismo; 2013.

[40] Abu-Zahra MRM, Niederer JPM, Feron PHM, Versteeg GF. CO2 capture from power plants. Part II. A parametric study of the economical performance based on monoethanolamine. Int J Greenh Gas Control 2007;1:135-42. doi:10.1016/S17505836(07)00032-1.

[41] De Saint Jean M, Baurens P, Bouallou C, Couturier K. Economic assessment of a power-to-substitute-natural-gas process including high-temperature steam electrolysis. Int J Hydrogen Energy 2015;40:6487-500. doi:10.1016/j.ijhydene.2015.03.066.

[42] Lehner M, Tichler R, Koppe M. Power-to-Gas : Technology and Business Model. Springer; 2014.

[43] Suhaib Muhammed Ali, Andrews J. Low-cost hydrogen storage options for solar hydrogen systems for remote area power supply. World Hydrog. Energy Conf., Lyon, France: 2006. 